\section{Effect of 1\% Povidone lodine Mouthwash/Gargle, Nasal and Eye Drop in COVID-19 patient}

\author{
Md. Iqbal Mahmud Choudhury', Nilufar Shabnam², Tazin Ahsan', Md. Saiful kabir, \\ Rashed Md. Khan ${ }^{5}$, S.M. Abu Ahsan ${ }^{6}$
}

${ }^{1}$ Assistant professor, Plastic Surgery Unit, Department of Surgery, Bangabandhu Sheikh Mujib Medical
University, Shahbag, Dhaka, Bangladesh. ${ }^{2}$ Assistant professor, Department of Surgery, BIRDEM Hospital \&
Ibrahim Medical College, Shahbag, Dhaka, Bangladesh. ${ }^{3}$ Medical officer, Upazila Health Complex,
Chowgacha, Jessore, Bangladesh. ${ }^{4}$ Professor and Head, Department of Dermatology and Venereology,
National Medical College, Dhaka, Bangladesh. ${ }^{5}$ Professor and Head, Department of Dermatology and
Venereology, Dhaka Medical College, Dhaka, Bangladesh. ${ }^{6}$ Associate Professor and Head, Ad-din Sakina
Medical college, Jessore, Bangladesh.
Bioresearch Communications

Volume 7, Issue 1, January 2021

Bioresearch

Communications

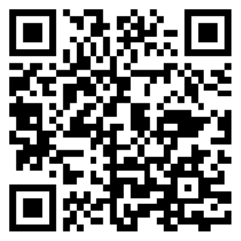

\begin{abstract}
Background: The sudden onset of COVID-19 began in late 2019 caused by a novel coronavirus (SARS-COV2) and on 11th March, WHO declared it to have developed pandemic status. There is still no specific treatment and vaccine available for COVID-19; causing wide spread health problem and concern of the globe. Povidone iodine (PVP-I) is an antiseptic that has been used for over 150 years. It is already proved that different concentration of PVP-I can deactivate COVID-19 virus. Methodology: In this randomized controlled clinical trial, out of 1113 patients 606 patients were enrolled and divided in 2 groups by randomization after taken consents. In Gr-A, 303 patients underwent mouthwash/gargle, nasal drops and eye drops with $1 \%$ povidone iodine 4 hourly for 4 weeks as well as symptomatic treatment according to need. In Gr-B 303 patients were advised mouthwash/gargle, nasal cavity and eye wash with lukewarm water 4 hourly for 4 weeks and symptomatic treatment according to need. RT-PCR test done every $3 \mathrm{rd}$, 5th and 7 th day and Thyroid hormone level (TSH, $\left.\mathrm{T}_{3}, \mathrm{~T}_{4}, \mathrm{FT}_{4}\right)$ at 4 th week for follow up. Results: The group of patients used $1 \%$ PVP-I have shown tremendously reduced mortality, morbidity and hospital as well as financial burden in this covid situation. Conclusion: Administration of $1 \%$ PVP-I as mouthwash/gargle, nasal or eye drop is simple, rapid and cost effective in reduction of mortality and morbidity by COVID-19.
\end{abstract}

KEYWORDS: Povidone lodine, 1Pq.S, COVID-19.

RECEIVED: 07 September 2020, ACCEPTED: 03 December 2020

TYPE: Original Research
CORRESPONDING AUTHOR: Dr. Md. Iqbal Mahmud Choudhury, assistant professor, Plastic Surgery Unit, Department of Surgery, Bangabandhu Sheikh Mujib Medical University, Shahbag, Dhaka.

Email: drimcrony@gmail.com Mobile: +8801713011283

\section{Introduction}

A strange situation has emerged among the people all over the world due to corona virus disease (COVID-19) due to its presence for uncertain time and severity of its consequences. Since December 2019, scientists and health-care workers are struggling for effective treatment plan and implementing strategies to control this pandemic. The nasal cavity, oropharynx and nasopharynx are the initial target cell of novel corona virus with the result saliva contains high viral load of COVID-19 with upto1.2 X10 ${ }^{8}$ infective copies $/ \mathrm{ml}^{1,2,3}$ The saliva is an important diagnostic tool for rapid mass detection. ${ }^{4}$ COVID-19 virus occupies host cells through two receptors: Angiotensin Converting Enzyme $2\left(\mathrm{ACE}_{2}\right)$ and $\mathrm{CD}_{147}$ (Basigen or EMMPRIN). Viral spike protein (SP) fixes to $\mathrm{ACE}_{2}$ or $\mathrm{CD}_{147}$ of host cell causing viral invasion, replication and spreading to other cells. ${ }^{5,6}$ Like RBCs and Type-II alveolar cells $\left(\mathrm{AT}_{2}\right)$ of lung. $\mathrm{CD}_{147}$ is also present in tear, alveolar tissues and retinal pigmented epithelium. ${ }^{7}$ So some sort of upper respiratory tract infection is due to binding of COVID-19 virus with $\mathrm{CD}_{147}$ in ocular tissues then travel into nasal cavity via naso-lacrimal duct. ${ }^{5,6}$ In case of COVID19 , initial interaction between its host receptor $\left(\mathrm{ACE}_{2}\right.$ or $\left.\mathrm{CD}_{147}\right)$ and spike protein (SP) are the initiating event in establishment of causing human host infection. ${ }^{8} \mathrm{~A}$ recent study done by Hou et al. shows that the ciliated cell with $\mathrm{ACE}_{2}$ expressions are most susceptible to infection which are more in the upper than lower air way cells. ${ }^{9}$ The study shows that a virus transmission pathway, which involves infection of ciliated cells of upper airway (nasal cavity) is the commonest site of infection followed by subsequent aspiration to lower airway and secondary to lungs. This process may play a role in systemic involvement and variable expression of clinical severity. ${ }^{10,11,12}$ Iodine is an effective anti-septic agent since 1800s. Povidone Iodine was discovered in 1955 by H.A. Shelanski and M.V. Shelanski. It is a water soluble polymer polyvinyl pyrrotodon (PVP-I) and less toxic than tincture of iodine. ${ }^{13}$ PVP-I is extensively used as a hand washing agent (as a $7.5 \%$ solution), for pre-procedure skin preparation (as a $10 \%$ solution), in ophthalmic surgery (as a 5\% solution) and in oral surgery (as a $10 \%$ solution). ${ }^{14,15,16}$ PVP-I is commercially available in Asia as a 1\% w/v mouthwash for use every 24hourly. ${ }^{17}$ The onset of antiseptic action of PVP-I starts when free form of iodine dissociate from the polymer complex which rapidly penetrates the microbes oxidizing the nucleic acid and its protein structures. PVP-I has higher virucidal activity than other commonly used anti-septic agents like chlorhexidine and benzalkonium chloride and shown to be active in vitro against SARS-COV (epidemic of 2002-03) \& 
MERS-COV (epidemic of 2012-13) virus. ${ }^{18,19,20}$ COVID-19 Virus is highly homologous to SARS virus. ${ }^{21}$ In vitro study on virucidal activity of povidone iodine against MERS \& SARS virus show that the lowest concentration of povidone iodine to effective was $1 \%$ when used for 30 seconds, leading to a reduction of viral activity of $\geq 99.99 \%{ }^{22}$ So, $1 \%$ PVP-I solution as mouthwash/gargle, nasal drop/spray and eye drop inactivate the heam agglutinin esterase activity as well as enhance absorption of $\mathrm{ACE}_{2}$ as receptor of host cell. ${ }^{23}$ Thus reduced the infectivity of host with systemic transmission and as well as cross infection.

\section{Materials and Methods}

Total 1113 patients from 1st February 2020 to 30th August 2020 in Bangladesh took treatment through telemedicine service of Anwar Khan Modern Medical College Hospital, Call A Doctor BD, Sebaghar. All patients were highly educated and belong to middle class family. They had very much hospital phobia in COVID-19 situation and wanted to take treatment at home isolation rather than in hospital. We used mobile calls, Viber, WhatsApp, e-mail and Zoom for communication and collection of data from patient or attending relative. RT-PCR positive patients who have done the test on 1st day of symptom (single or multiple symptoms fever, body ache, headache, loss of smell, loss of taste, sore throat, diarrhea, skin rash, shortness of breath, redness of the eyes), age more than 10 years and less than 90 years were included in this study. Patients with history of allergy to povidone iodine, all form of thyroid diseases or on radioactive iodine treatment, known pregnancy, renal failure and malignancy were excluded. 606 patients were enrolled and divided in 2 groups by randomization after taken consents. In Gr-A, 303 patients underwent mouthwash/gargle, nasal drops and eye drops with $1 \%$ povidone iodine 4 hourly for 4 weeks as well as symptomatic treatment according to need. In Gr-B, 303 patients were advised mouthwash/gargle, nasal cavity and eye wash with lukewarm water 4 hourly for 4 weeks and symptomatic treatment according to need. RT-PCR test done every 3rd, 5th and 7th day and Thyroid hormone level (TSH, $\left.\mathrm{T}_{3}, \mathrm{~T}_{4}, \mathrm{FT}_{4}\right)$ at 4 th week for follow up. Some patients required hospitalization were admitted in of Anwar Khan Modern Medical College Hospital. The study protocol was approved by the ethical committee of Anwar Khan Modern Medical College Hospital. Analysis was performed by using a computer based statistical program SPSS (Statistical Package for Social Sciences) version 16. Quantitative data were expressed as means $\pm \mathrm{SD}$. $95 \%$ confidence interval was calculated and $\mathrm{p}$ value of $<0.05$ was considered as significance.

Preparation and Method of Application of 1\% PVP-I -

$10 \%$ PVP-I is found all over the country. But $1 \%$ commercially available PVP-I is found only in a few cities or town. Most of the 1\% PVP-I was formed from 10\% PVP-I in the following manner - Povidone Iodine $1 \mathrm{P} 10 \% \mathrm{v} / \mathrm{w}$ in purified water $1 \mathrm{P}$ q.s. Therefore, use $1 \mathrm{~mL}$ of PVP-I in $10 \mathrm{~mL}$ of sterile water/purified water. 1\% PVP-I is introduced into oral cavity as mouth wash. Care is taken to ensure the solution is distributed throughout the oral cavity for 30 seconds and then gently gargled or, held at the back of the throat for another 30 seconds before spitting out. Then 4-5 drops of $1 \%$ PVP-I is introduced to wash the nostrils by dropper and 2 drops in each eye. This application is done 4 hourly for 4 weeks.

\section{Results}

In the study, more affected are male $(79.87 \%, \mathrm{~N}-484)$ than female $(20.13 \%, \mathrm{~N}-122)$. The differences were not statistically significant $(\mathrm{P}>0.05)$. More $(39.93 \%)$ patients are in the $31-50$ years age group, followed by $34.65 \%$ in the $51-70$ years age group (Table -1). In group A (patients used PVP-I), only $2.64 \%(\mathrm{~N}-8)$ patient is RT-PCR positive on the 7 th day whereas in group B (patients used lukewarm water), it is $70.30 \%(\mathrm{~N}-213)$ (Table 2, Gr- A \& B) ( $>>0.05)$. Data of Table $3(\mathrm{Gr}-\mathrm{A} \& \mathrm{~B})$ shows that $3.30 \%(\mathrm{~N}-10)$ hospitalized patients of group A needed oxygen support (by mechanical ventilator and/or high flow nasal cannula and/or non rebreather mask and/or face mask and/or nasal cannula) but $20.79 \%$ (N-63) patients of group B needed oxygen support. Mortality rate is high $5.6 \%(\mathrm{~N}-17)$ in group $\mathrm{B}$ than $0.66 \%(\mathrm{~N}-2)$ in group $\mathrm{A}$. The differences were statistically significant $(\mathrm{P}<0.05)$.

Table-1. Age and Sex Distributions of patients

\begin{tabular}{lllllll}
\hline Age Group(yrs) & & Male & & Female & \multicolumn{2}{c}{ Total } \\
\hline $\mathbf{1 1 - 3 0}$ & $\mathbf{7 2}$ & $11.88 \%$ & 18 & $2.97 \%$ & 90 & $14.85 \%$ \\
$\mathbf{3 1 - 5 0}$ & 193 & $31.85 \%$ & 49 & $8.09 \%$ & 242 & $39.93 \%$ \\
$\mathbf{5 1 - 7 0}$ & 167 & $27.56 \%$ & 43 & $7.10 \%$ & 210 & $34.65 \%$ \\
$\mathbf{7 1 - 9 0}$ & 52 & $8.58 \%$ & 12 & $1.98 \%$ & 64 & $10.56 \%$ \\
& 484 & $79.87 \%$ & 122 & $20.13 \%$ & 606 & $100 \%$ \\
\hline
\end{tabular}

Table-2. Gr-A( RT-PCR test result using PVP-I)

\begin{tabular}{lllllll}
\hline $\begin{array}{l}\text { Age Group } \\
\text { (yrs) }\end{array}$ & \multicolumn{2}{l}{$\begin{array}{l}\text { RT-PCR test positive on } 3^{\text {rd }} \\
\text { day }\end{array}$} & $\begin{array}{l}\text { RT-PCR test positive on } 5^{\text {th }} \\
\text { day }\end{array}$ & \multicolumn{2}{l}{$\begin{array}{l}\text { RT-PCR test positive on } \mathbf{7}^{\text {th }} \\
\text { day }\end{array}$} \\
$\mathbf{1 1 - 3 0}$ & Male & Female & Male & Female & Male & Female \\
$\mathbf{3 1 - 5 0}$ & 2 & 1 & 1 & 0 & 0 & 0 \\
$\mathbf{5 1 - 7 0}$ & 6 & 3 & 4 & 2 & 0 & 1 \\
$\mathbf{7 1 - 9 0}$ & 7 & 5 & 6 & 3 & 2 & 1 \\
& 7 & 4 & 5 & 3 & 3 & 1 \\
& $22(7.26 \%)$ & $13(4.29 \%)$ & $16(5.25 \%)$ & $8(2.64 \%)$ & $5(1.65 \%)$ & $3(0.99 \%)$ \\
\hline
\end{tabular}


Table-2. Gr-B (RT-PCR test result using lukewarm water)

\begin{tabular}{lllllll}
\hline \multirow{2}{*}{$\begin{array}{l}\text { Age Group } \\
(\mathbf{y r s})\end{array}$} & \multicolumn{2}{l}{$\begin{array}{l}\text { RT-PCR test positive on } 3^{\text {rd }} \\
\text { day }\end{array}$} & $\begin{array}{l}\text { RT-PCR test positive on } 5^{\text {th }} \\
\text { day }\end{array}$ & \multicolumn{2}{l}{$\begin{array}{l}\text { RT-PCR test positive on }^{\text {th }} \\
\text { day }\end{array}$} \\
\cline { 2 - 6 } $\mathbf{1 1 - 3 0}$ & Male & Female & Male & Female & Male & Female \\
$\mathbf{3 1 - 5 0}$ & 33 & 9 & 29 & 6 & 20 & 3 \\
$\mathbf{5 1 - 7 0}$ & 95 & 23 & 91 & 19 & 81 & 15 \\
$\mathbf{7 1 - 9 0}$ & 80 & 20 & 77 & 18 & 62 & 12 \\
& 26 & 75 & 24 & 4 & 18 & 2 \\
& $235(77.22 \%)$ & $57(18.81 \%)$ & $221(72.937 \%)$ & $47(15.51 \%)$ & $181(59.735 \%)$ & $32(10.56 \%)$ \\
\hline
\end{tabular}

Table-3. Gr-A (Total outcome after using PVP-I)

\begin{tabular}{lllllll}
\hline \multirow{2}{*}{$\begin{array}{l}\text { Age Group } \\
\text { (yrs) }\end{array}$} & Hospitalized & \multicolumn{4}{l}{ Hospitalized + Oxygen support } & Death \\
\cline { 2 - 7 } $\mathbf{1 1 - 3 0}$ & Male & Female & Male & Female & Male & Female \\
$\mathbf{3 1 - 5 0}$ & 0 & 0 & 0 & 0 & 0 & 0 \\
$\mathbf{5 1 - 7 0}$ & 1 & 0 & 0 & 0 & 0 & 0 \\
$\mathbf{7 1 - 9 0}$ & 0 & 0 & 4 & 1 & 1 & 0 \\
& 1 & 0 & 3 & 2 & 1 & 0 \\
& $2(0.66 \%)$ & 0 & $7(2.31 \%)$ & $3(0.99 \%)$ & $2(0.66 \%)$ & 0 \\
\hline
\end{tabular}

Table-3. Gr-B (Total outcome after using lukewarm water)

\begin{tabular}{lllllll}
\hline \multirow{2}{*}{$\begin{array}{l}\text { Age Group } \\
\text { (yrs) }\end{array}$} & Hospitalized & \multicolumn{3}{l}{ Hospitalized + Oxygen support } & Death \\
\cline { 2 - 6 } $\mathbf{1 1 - 3 0}$ & Male & Female & Male & Female & Male & Female \\
$\mathbf{3 1 - 5 0}$ & 0 & 0 & 7 & 1 & 0 & 0 \\
$\mathbf{5 1 - 7 0}$ & 5 & 2 & 16 & 5 & 3 & 1 \\
$\mathbf{7 1 - 9 0}$ & 5 & 0 & 11 & 9 & 6 & 0 \\
& 1 & 1 & 9 & 5 & 5 & 2 \\
& $11(3.63 \%)$ & $3(0.99 \%)$ & $43(14.19 \%)$ & $20(6.60 \%)$ & $14(4.62 \%)$ & $3(0.99 \%)$ \\
\hline
\end{tabular}

\section{Discussion}

There are no established effective therapies or vaccines for COVID-19 infection still today, so treatment relies mostly on supportive care, oxygen support with or without mechanical ventilation and medication previously employed against SARS-Cov, MARS-Cov. ${ }^{24}$ Povidone Iodine (PVP-I) is very much effective virucidal and well tolerable mouthwash/ gargle, nasal spray and eye drop than other antiseptics which working against SARC-Cov and MARS-Cov is already proven. ${ }^{25,26}$ Free iodine release from aqueous solution of PVPI which likely attack surface proteins of enveloped virus and destabilizes membrane fatty acid by reacting with unsaturated carbon bond. ${ }^{27,28,29,30}$ It is already proved that binding with iodine to the lipid component of enveloped virus increases susceptibility over non enveloped viruses. ${ }^{31}$ COVID-19 virus belongs to a family of enveloped, single-stranded RNA corona virus. ${ }^{32}$ Some recent studies has shown that PVP-I inactivate MERS-Cov and SARS-Cov which has nearly identical genomes to COVID-19 virus. ${ }^{33}$ Concentration of $0.23-1 \%$ PVP-I reduced infectivity below detectable level within 2 minutes. ${ }^{34}$ In recent months, susceptibility to PVP-I solutions has been confirmed for COVID-19 virus. After 30 seconds, $\geq$
99.99\% virucidal activity against COVID-19 was found for a $1 \%$ PVP-I mouth wash and a $0.45 \%$ PVP-I throat spray. ${ }^{35}$ COVID-19 viral load are high in nasal cavity, nasooropharynx, lymphocyte of oral tissues, goblet and ciliated cells within respiratory epithelium of nose have the highest expression of $\mathrm{ACE}_{2}$, the main receptor of COVID-19 virus and some accidental ocular exposure $\mathrm{CD}_{147}$, also receptor of COVID-19 virus. ${ }^{36}$ PVP-I of $0.5-10 \%$ solution inactivate the $\mathrm{ACE}_{2}$ and $\mathrm{CD}_{147}$ receptor of host cell. In our study, patients of Gr-A (those who used 1\% PVP-I) are tremendously improved over Gr-B (those who used only lukewarm water) in terms of RT-PCR test result, mortality, hospitalization with or without oxygen support (Table- $2 \& 3$ ). In table- 2 , only $11.55 \%$ patient's show RT-PCR test positive in Gr-A on 3rd day where as 96.04\% is positive in Gr-B. On the other hand, 2.64\% patient is positive on 7th day in Gr-A and $70.30 \%$ positive in Gr-B. So, it is clear that $1 \%$ PVP-I can vigorously reduce the viral load in oral cavity, nasal cavity and naso-oropharynx. This information is also supported by an in vivo study done by Martinez Lams et al in June 2020; aimed to determine the influence of $1 \%$ PVP-I on COVID-19 positive patients. ${ }^{37}$ They evaluated and compared the viral load of the saliva of 
those patients after 1 minute use of 1\% PVP-I and effects persisted for 3 hours. Another study done by Sarfaraz et al also support our study results. ${ }^{37}$ In Table-3, Gr-A shows only $0.66 \%$ mortality over $5.61 \%$ of Gr-B and only $3.30 \%$ hospitalized patients need oxygen support in Gr-A in comparison to $20.79 \%$ in Gr-B. So the patients those who used $1 \%$ PVP-I have minimum mortality, morbidity and occupying minimum number of hospital bed causing less burden to health and financial sector of Bangladesh in COVID-19 pandemic situation. Hou et al recently demonstrated that COVD-19 virus initially infects ciliated cell of nasal cavity. The virus then spreads via nasal-oropharynx to lungs through micro aspiration and causes pulmonary infection which is then form further devastating systemic involvement via blood. ${ }^{9}$ The use of 1\% PVP-I as mouth wash/gargle, nasal and eye drop has also been recommended to reduced viral load in oral cavity, naso-oropharynx and thus to prevent systemic infection as well as accelerate recovery of these patients. ${ }^{39,40}$ In Ader's study, 6 months use of daily 5\% PVP-I mouthwash/rinse, nasal wash caused no change in serum $\mathrm{T}_{3}, \mathrm{~T}_{4}$ or $\mathrm{FT}_{4} \cdot{ }^{41}$ In this study, we found no change in serum $\mathrm{TSH}, \mathrm{T}_{3}, \mathrm{~T}_{4}$ or $\mathrm{FT}_{4}$ after 4 weeks (4 times a day) use of $1 \%$ PVP-I. PVP-I is a broad spectrum antiseptic with no known resistance that has listed by WHO as an essential medicine. ${ }^{42}$ PVP-I is broadly virucidal; a recently developed eye/nasal/oral formulation has been shown to rapidly deactivated COVID-19 virus. ${ }^{43}$

\section{Conclusion}

Administration of 1\% PVP-I as mouthwash/gargle, nasal or eye drop is simple, rapid and cost effective in reduction of mortality and morbidity by COVID-19. In this horrible situation, simple use of $1 \%$ PVP-I can change the treatment modality of COVID-19 patient and reduce the hospital as well as financial burden of the globe.

\section{Reference}

1.To KKW, Tsang OTY, Yip CCY, Chan KH, Wu TC, Chan JMC, et al. Leung, W.S., Chik, T.S.H., Choi, C.Y.C., Kandamby, D.H. and Lung, D.C.,. Consistent detection of 2019 novel coronavirus in saliva.Clinical Infectious Diseases. 2020; 71:pp841-843.

2. Zou L, Ruan F, Huang M, Liang L, Huang H, Hong Z, et al. SARS-CoV-2 viral load in upper respiratory specimens of infected patients.New England Journal of Medicine, 2020; 382(12): pp.11771179.

3. Khurshid Z, Asiri FYI and Al Wadaani H. Human saliva: Noninvasive fluid for detecting novel coronavirus (2019-nCoV). International Journal of Environmental Research and Public Health. 2020; 17(7): pp.2225.

4. Hamid H, Khurshid Z, Adanir N, Zafar MS and Zohaib S. COVID19 Pandemic and Role of Human Saliva as a Testing Biofluid in Point-of-Care Technology.European Journal of Dentistry. 2020;04: pp.1-7.

5. Wang K, Chen W, Zhou YS, Lian JQ, Zhang Z, Du P, et al. SARSCoV-2 invades host cells via a novel route: CD147-spike protein. BioRxiv. 2020.

6. Yan R, Zhang Y, Li Y, Xia L, Guo Y and Zhou Q. Structural basis for the recognition of SARS-CoV-2 by full-length human ACE2.Science. 2020; 367(6485): pp.1444-1448.
7. Parikh SR, Bly RA, Bonilla-Velez J, Dahl JP, Evans SS, Horn DL, et al. Pediatric otolaryngology divisional and institutional preparatory response at Seattle Children's Hospital after COVID-19 regional exposure. Otolaryngology-Head and Neck Surgery. 2020: p.0194599820919748.

8. Sarma P, Prajapat M, Avti P, Kaur H, Kumar S and Medhi B. Therapeutic options for the treatment of 2019-novel coronavirus: An evidence-based approach. Indian journal of pharmacology. 2020; 52(1): pp.1.

9. Hou YJ, Okuda K, Edwards CE, Martinez DR, Asakura T, Dinnon III KH, et al. SARS-CoV-2 Reverse Genetics Reveals a Variable Infection Gradient in the Respiratory Tract. Cell. 2020.

10. Sarma P, Kaur H, Kaur H, Bhattacharyya J, Prajapat M, Shekhar $\mathrm{N}$, et al. Ocular manifestations and tear or conjunctival swab PCR positivity for 2019-nCoV in patients with COVID-19: a systematic review and meta-analysis. 2020; Available at SSRN 3566161.

11. Wu P, Duan F, Luo C, Liu Q, Qu X, Liang L, et al. Characteristics of ocular findings of patients with coronavirus disease 2019 (COVID-19) in Hubei Province, China. JAMA ophthalmology, 2020; 138(5): pp.575-578.

12. Wölfel R, Corman VM, Guggemos W, Seilmaier M, Zange S, Müller MA, et al. Virological assessment of hospitalized patients with COVID-2019.Nature. 2020; 581(7809): pp.465-469.

13. Wada H, Nojima Y, Ogawa S, Hayashi N, Sugiyama N, Kajiura $\mathrm{T}$, et al. Relationship between virucidal efficacy and free iodine concentration of povidone-iodine in buffer solution. Biocontrol Science. 2016; 21(1): pp.21-27.

14. Urias DS, Varghese M, Simunich T, Morrissey, S and Dumire R. Preoperative decolonization to reduce infections in urgent lower extremity repairs.European Journal of Trauma and Emergency Surgery. 2018; 44(5): pp.787-793.

15. Koerner JC, George MJ, Meyer DR, Rosco MG and Habib MM. Povidone-iodine concentration and dosing in cataract surgery. Survey of ophthalmology.2018;63(6): pp.862-868.

16. Silas MR, Schroeder RM, Thomson RB and Myers WG. Optimizing the antisepsis protocol: Effectiveness of 3 povidoneiodine $1.0 \%$ applications versus a single application of povidoneiodine 5.0\%. Journal of Cataract \& Refractive Surgery. 2017; 43(3): pp.400-404.

17. Domingo MA, Farrales MS, Loya RM, Pura MA and Uy H. The effect of $1 \%$ povidone iodine as a pre-procedural mouthrinse in 20 patients with varying degrees of oral hygiene.The Journal of the Philippine Dental Association. 1996; 48(2): pp.31-38.

18. da Silveira Teixeira D, de Figueiredo MAZ, Cherubini K, de Oliveira SD and Salum FG. The topical effect of chlorhexidine and povidone-iodine in the repair of oral wounds. A review.Stomatologija. 2019;21(2): pp.35-41.

19. Eggers M, Eickmann M and Zorn J. Rapid and effective virucidal activity of povidone-iodine products against Middle East respiratory syndrome coronavirus (MERS-CoV) and modified vaccinia virus Ankara (MVA).Infectious diseases and therapy. 2015; 4(4): pp.491501.

20. Lange C, Wolf J, Auw-Haedrich C, Schlecht A, Boneva S, Lapp T, et al. Expression of the COVID-19 receptor ACE2 in the human conjunctiva.Journal of Medical Virology. 2020; 92(10)pp.2081-2086. 
21. Zheng J. SARS-CoV-2: an emerging coronavirus that causes a global threat. International journal of biological sciences. 2020; 16(10): pp.1678.

22. Eggers M, Koburger-Janssen T, Eickmann M and Zorn J. In vitro bactericidal and virucidal efficacy of povidone-iodine gargle/mouthwash against respiratory and oral tract pathogens.Infectious diseases and therapy. 2018; 7(2): pp.249-259.

23. Eggers M. Infectious disease management and control with povidone iodine. Infectious diseases and therapy. 2019;8 pp.581-593.

24. Cascella M, Rajnik M, Cuomo A, Dulebohn SC and Di Napoli R. Features, evaluation and treatment coronavirus (COVID-19).In Statpearls [internet].StatPearls Publishing. 2020.

25. Kirk-Bayley J, Challacombe S, Sunkaraneni S and Combes J. The Use of Povidone Iodine Nasal Spray and Mouthwash During the Current COVID-19 Pandemic May Protect Healthcare Workers and Reduce Cross Infection. 2020; Available at SSRN 3563092.

26. Shiraishi $T$ and Nakagawa Y. Evaluation of the bactericidal activity of povidone-iodine and commercially available gargle preparations .Dermatology. 2002; 204(Suppl. 1): pp.37-41.

27. Cooper RA. Iodine revisited. International wound journal. 2007; 4(2): pp.124-137.

28. Park SE. Epidemiology, virology, and clinical features of severe acute respiratory syndrome-coronavirus-2 (SARS-CoV-2; Coronavirus Disease-19).Clinical and experimental pediatrics, 2020; 63(4): pp.119.

29.Walls AC, Park YJ, Tortorici MA, Wall A, McGuire AT and Veesler D. Structure, function, and antigenicity of the SARS-CoV-2 spike glycoprotein. Cell. 2020.

30. Bigliardi PL, Alsagoff SAL, El-Kafrawi HY, Pyon JK, Wa CTC and Villa MA. Povidone iodine in wound healing: A review of current concepts and practices. International Journal of Surgery. 2017; 44: pp.260-268.

31. Lu R, Zhao X, Li J, Niu P, Yang B, Wu H, et al. Genomic characterisation and epidemiology of 2019 novel coronavirus: implications for virus origins and receptor binding. The Lancet, 2020; 395(10224): pp.565-574

32. Kariwa H, Fujii $\mathrm{N}$ and Takashima I. Inactivation of SARS coronavirus by means of povidone-iodine, physical conditions and chemical reagents.Dermatology. 2006; 212(Suppl. 1): pp.119-123

33. Van DN, Bushmaker T, Morris DH, Holbrook MG, Gamble A, Williamson BN, et al. Aerosol and surface stability of SARS-CoV-2 as compared with SARS-CoV-1.New England Journal of Medicine. 2020; 382(16): pp.1564-1567

34. Eggers M, Eickmann M and Zorn J. Rapid and effective virucidal activity of povidone-iodine products against Middle East respiratory syndrome coronavirus (MERS-CoV) and modified vaccinia virus Ankara (MVA).Infectious diseases and therapy. 2015; 4(4): pp.491501.

35. Kanagalingam J, Feliciano R, Hah JH, Labib H, Le TA and Lin JC. Practical use of povidone-iodine antiseptic in the maintenance of oral health and in the prevention and treatment of common oropharyngeal infections. International journal of clinical practice. 2015; 69(11): pp.1247-1256.

36. Pelletier J, Tessema B, Westover J, Frank S, Brown S and Capriotti J. In Vitro Efficacy of Povidone-Iodine Nasal And Oral Antiseptic Preparations Against Severe Acute Respiratory SyndromeCoronavirus 2 (SARS-CoV-2). medRxiv. 2020.

37. Martínez LL, Diz DP, Pérez RMT, Del CPV, Cabrera AJJ, López DAM, et al. Is povidone iodine mouthwash effective against SARSCoV-2.First in vivo tests. Oral diseases. 2020.

38. Eggers M, Koburger-Janssen T, Eickmann M and Zorn J. In vitro bactericidal and virucidal efficacy of povidone-iodine gargle/mouthwash against respiratory and oral tract pathogens. Infectious diseases and therapy. 2018; 7(2): pp.249-259

39. Kawana A and Kudo K. A trial of povidone-iodine (PVP-I) nasal inhalation and gargling to remove potentially pathogenic bacteria colonized in the pharynx. Kansenshogakuzasshi. The Journal of the Japanese Association for Infectious Diseases. 1999; 73(5): pp.429436

40. Kirk-Bayley J, Combes J, Sunkaraneni S and Challacombe S. The use of Povidone iodine nasal spray and mouthwash during the current COVID-19 pandemic may reduce cross infection and protect healthcare workers. 2020; Available at SSRN 3563092.

41. Ader AW, Paul TL, Reinhardt W, Safran M, Pino SAM, McArthur, et al. Effect of mouth rinsing with two polyvinylpyrrolidone-iodine mixtures on iodine absorption and thyroid function.The Journal of Clinical Endocrinology \& Metabolism. 1988; 66(3): pp.632-635.

42. World Health Organization. 19th WHO model list of essential medicines. World Health Organization, Geneva, Switzerland. 2015.

43. Pelletier J, Tessema B, Westover J, Frank S, Brown S and Capriotti J. In Vitro Efficacy of Povidone-Iodine Nasal And Oral Antiseptic Preparations Against Severe Acute Respiratory SyndromeCoronavirus 2 (SARS-CoV-2). medRxiv. 2020. 